\title{
Educando para a cidadania: A experiência da escola do Legislativo*
}

\author{
Luiz Fernandes de Assis**
}

RESUMO: Este artigo apresenta a Escola do Legislativo, uma idéia pioneira da Assembléia Legislativa de Minas Gerais, como capaz de oferecer conhecimento e de estimular a reflexão, nas áreas de ensino, pesquisa e extensão. Após um breve histórico de sua criação, relata o avanço da Escola para uma prática editorial e pedagógica de uma educação para a cidadania e o desafio de usar ferramentas tecnológicas adequadas: a televisão e a Internet. $\mathrm{O}$ artigo não se omite ao revelar os limites institucionais e históricos para uma participação verdadeiramente cidadã e democrática: a subserviência do Legislativo ao Executivo, o clientelismo nas relações entre o representante e o representado, o corporativismo parlamentar e a impunidade.

Palavras-chave: Escola, Legislativo, cidadania, educação, história

\section{Antecedentes}

Para entender a criação e o trabalho que a Escola do Legislativo desenvolve, devemos recuar no tempo, até o ano de 1986. Nesse ano, foi realizado o Simpósio Minas Gerais e a Constituinte, ${ }^{1}$ no qual várias

* Este texto serviu de base à nossa exposição na 46ª Reunião Anual da SBPC como parte da mesa-redonda "Educando para a cidadania: Três experiências da sociedade civil", em Vitória (ES), no dia 21 de julho de 1994. O texto sofreu uma atualização de dados e opiniões, para esta publicação.

** Historiador e coordenador de Pesquisa e Extensão da Escola do Legislativo - Assembléia Legislativa do Estado de Minas Gerais. 
entidades de classe, entre outros representantes da sociedade civil, foram convidadas pela Assembléia Legislativa de Minas Gerais a participar da discussão dos grandes temas que seriam objeto de análise e definição por parte da Assembléia Nacional Constituinte, que se aproximava.

A experiência de convidar e chamar à participação a sociedade mais organizada foi extremamente rica e encorajou a instituição a prosseguir no estreitamento desses contatos, que, afinal, seriam repetidos quando da Constituinte Estadual. Um dado das eleições de 1986 surpreendeu a todos: houve uma renovação de mais de $70 \%$ no corpo parlamentar. Isso revelava um desgaste muito grande da imagem pública do político e uma insatisfação absoluta com os representantes da época.

No trabalho cotidiano da Constituinte Estadual, notou-se a urgente necessidade de uma maior profissionalização de todo o corpo técnico, notadamente dos funcionários ligados ao processo legislativo (comissões, consultoria e Plenário).

A partir de maio de 1989 houve uma mudança estratégica na forma de composição dos gabinetes parlamentares e da parte administrativa da Assembléia. O deputado passou a dispor de maior flexibilidade na composição de sua assessoria, podendo mesmo indicar livremente todos os funcionários, desde o simples digitador até os assessores mais próximos. Os funcionários efetivos, antes lotados nesses gabinetes, foram deslocados para a Administração. Foi instalado nos gabinetes um sistema de pontuação na distribuição dos cargos, o que permitiu a adequação da estrutura às peculiaridades de trabalho de cada deputado. Assegurou-se sempre um mesmo valor de despesa por gabinete. Isso significava que cada deputado poderia montá-lo com quantos assessores de confiança desejasse, desde que não ultrapassasse o montante estipulado para todos.

Essa decisão de deixar os deputados livres para arregimentar seu corpo funcional revelou-se extremamente fecunda para o staff administrativo da Assembléia Legislativa, uma vez que, a partir daquele instante, os parlamentares não interfeririam mais nas definições da estrutura funcional do Poder Legislativo. (Estou chamando de "staff administrativo" aos cargos de direção do corpo funcional centralizados na figura da Diretoria Geral.) Novos funcionários para a administração seriam aceitos apenas através de concurso público e a escolha dos ocupantes dos cargos de direção não passaria mais pelo crivo de peso político parlamentar. Hoje, quando 
a Assembléia Legislativa é freqüentemente visitada por funcionários de Legislativos de outros estados, uma primeira providência que sugerimos é essa separação nítida e irreversível. Uma decisão que, diga-se de passagem, agradou a ambas as partes. O parlamentar, com a possibilidade de ampliar e atender a maior demanda de suas bases (um emprego), não necessitava mais submeter-se ao constrangimento de solicitar um cargo à administração da Casa. Acrescente-se que, obviamente, toda a estrutura material é rigorosamente suprida pela Administração e que todos os funcionários lotados nos gabinetes, quando do término do mandato, perdem o direito de continuar trabalhando na Assembléia, esta, sim, uma prática nociva que rondou o Parlamento mineiro durante anos.

A partir daí, foi possível pensar e desenvolver programas de profissionalização de carreira e racionalização do trabalho legislativo.

\section{Pesquisa de opinião e sociedade civil}

Talvez não haja ninguém mais suscetível aos efeitos da opinião pública do que o político profissional. Muitas de suas posturas são condicionadas pelos sinais que vêm da sociedade. Um exemplo claro foi o impedimento do presidente da República Fernando Collor de Mello, em 1992, pelo mesmo corpo parlamentar que aprovou no Congresso Nacional o seu plano de estabilização, no qual estava embutido um confisco financeiro inédito (também legitimado pelas urnas da véspera).

Em 1990, realizamos pesquisa de opinião para sentir o quanto a imagem do Legislativo estava desgastada, e por onde poderíamos buscar reverter o quadro. Os dados foram alarmantes.

Depois disso, o staff administrativo da Assembléia decidiu organizar-se para, de maneira ativa, estreitar laços com a sociedade civil, reverter esse quadro tão negativo e chamar os vários segmentos sociais para conhecer as possibilidades que o Poder Legislativo Estadual oferece. Ao contrário do Executivo, no qual há um único mandatário, portanto uma única porta de influência, e do Judiciário, em que esta deve manter-se cerrada, pois seus titulares exigem isenção, o Legislativo mantém hoje, no mínimo, 77 possibilidades de influência por parte da sociedade. Queríamos, no entanto, fugir desse modelo, pois se revela eivado de vícios do clientelismo e do paternalismo. Era preciso ousar e descobrir novos instrumentos de atuação popular. 
O ano de 1991 foi importante pela implementação de um Plano Plurianual de Ação Governamental para o quadriênio 1992/1995, definido por dispositivo constitucional e realizado em conjunto com os outros dois Poderes. Nesse Plano todos davam ciência aos demais de suas intenções e expectativas. Por se antever uma ação mais agressiva do Poder Legislativo Estadual no sentido de alcançar a sociedade civil e ampliar sua capacidade de atuação, foi solicitada e cumprida a disponibilidade financeira prevista nos orçamentos anuais. Com uma remuneração condigna e pontualmente paga, os funcionários da Alemg não tinham por que não se engajar nessa meta institucional. A péssima imagem do político enlameava-nos todos e o real esforço foi sempre o de demonstrar seriedade e dignidade no trabalho realizado, e justiça no valor remuneratório. Não queríamos, e ainda não queremos, ver o Legislativo Estadual com a fama de um prostíbulo risonho. ${ }^{2}$

Desde a Propaganda Republicana, na década de 70 do século passado, vários segmentos da sociedade (principalmente na hoje chamada classe média) lutaram para que o ingresso nos cargos públicos se pautasse por critérios de mérito e não mais por seus talentos e virtudes, como definia a Constituição outorgada por Pedro I e seguida durante todo o período monárquico. Sabemos, porém, que nem os mandatários republicanos seguiram o que pregaram, e que as distorções das ditaduras militares sufragaram um corpo funcional de apaniguados que ainda hoje se faz sentir. Quem ainda duvida que a base funcional da estrutura administrativa do país, em seus $2^{\circ}$ e $3^{\circ}$ escalões, tenha sido montada pelos membros da Arena (Aliança Renovadora Nacional), partido criado para legitimar os militares no poder, ou pelos do MDB (Movimento Democrático Brasileiro), sua oposição mais confiável?

Nas assembléias legislativas, nos estados, esta prática não foi diferente. Em Minas Gerais, somente a partir da década de 1980 instituiuse a prática de concursos públicos realizados por fundações independentes e de ilibada reputação. A Constituição Estadual de 1989 vedou, absolutamente, quaisquer outras formas de ingresso além do concurso público. Diga-se, a bem da verdade, não sem antes promover um vergonhoso concurso interno, para legitimar os apaniguados que entraram por baixo do pano.

As exceções de sempre, também aqui, fizeram-se presentes.

A cada concurso - e com as novas demandas que a democracia representativa requer, dadas as suas inéditas prerrogativas, houve vári- 
os concursos - arregimentavam-se profissionais gabaritados para não só cumprir as funções já definidas em edital, mas também repensar a instituição e expressar idéias próprias.

A idéia de uma escola

Em fins de 1991, formou-se o primeiro grupo para viabilizar uma Escola do Legislativo. Ela teria, entre outras atribuições: profissionalizar, ao máximo, todos os funcionários da Assembléia (tanto os de gabinete como os da administração), servir de canal de repasse de informações, conhecimentos e métodos de trabalho; e, por fim, criar um espaço de reflexão política para o questionamento filosófico das práticas representativas.

A efetivação da Escola do Legislativo, no entanto, só foi possível em 1993.

Nesse ínterim, surgiu a oportunidade de exercitar uma atuação pedagógica mais agressiva junto às escolas públicas do Estado. Por ocasião do bicentenário da morte de Tiradentes, em 1992, queríamos fugir daquelas formas de comemorações surradamente conhecidas. Propusemos, e foi aceita, a idéia de elaboração de um vídeo educativo Tiradentes Duzentos Anos -, acompanhado de um livreto para o professor de história, em que trabalharíamos, através da música barroca, imagem e texto, o clima e os acontecimentos que desembocaram no que se convencionou chamar de Inconfidência Mineira, e discutiríamos a construção do mito Tiradentes, tanto no silêncio imperial como na sua apropriação política pelos vários governos republicanos. Com um resultado satisfatório em mãos (dado o profissionalismo das equipes envolvidas - e aqui não hesitamos em terceirizar a produção videográfica), reproduzimos 500 cópias, e, num convênio com a Secretaria do Estado da Educação, fizemos com que chegassem gratuitamente às escolas públicas de $2^{\circ}$ grau, já que o conteúdo proposto atingia a faixa etária correspondente. Não temos ainda um feedback da repercussão junto aos alunos por falta de uma pesquisa consistente, mas já recebemos algumas críticas e alguns elogios dos corpos docente e discente das escolas. Infelizmente, o áudio da fita reproduzida em série deixou a desejar. $\mathrm{O}$ que antes fora imaginado para ser exibido em grandes espaços teve que ser visto em sala pequena. Enfim, o espaço privado venceu o espaço público. 
Quando a Assembléia Legislativa instalou definitivamente a Escola do Legislativo, em 1993, uma série de atividades junto à sociedade civil já se fazia presente. Isso requeria um entendimento mínimo das atividades ligadas à elaboração das leis e à fiscalização do Executivo. Com esse quadro, a Escola definiu como prioridade "constituir um repertório de informações para subsidiar a elaboração de projetos e demais proposições legislativas, bem como o processo legislativo e os controles interno e externo". ${ }^{3}$ Em suma: tentar ensinar a todos os funcionários da Alemg os mecanismos mínimos de seu ofício, uma introdução à Teoria Geral do Estado e ao Constitucionalismo e as noções básicas do Direito e da Administração Pública.

Sua primeira estrutura funcional interna, já extinta, foi assim distribuída: Diretoria, Conselho Escolar (órgão consultivo e deliberativo) e três Coordenadorias - do Núcleo Comum, do Núcleo Específico e de Programas Especiais.

A Coordenadoria do Núcleo Comum instituía sempre um Curso de Atualização do Servidor, através do qual seriam repassados os conteúdos daquelas disciplinas que atendiam às prioridades definidas anteriormente, ou seja, que subsidiariam a elaboração de projetos e demais proposições legislativas.

A Coordenadoria do Núcleo Específico atenderia a demandas localizadas por setor. Como exemplo, tínhamos o curso de Procedimentos Regimentais, para áreas de apoio direto às atividades-fim do Poder, como a Secretaria Geral da Mesa ou a Secretaria Temático-Processual.

A Coordenadoria de Programas Especiais visava criar um ambiente propício à reflexão política, no qual vários pensadores do Brasil e do Exterior seriam convidados para debater livremente suas idéias ou os temas mais candentes do momento. Esse núcleo tinha como público-alvo os deputados estaduais, seus assessores e os funcionários da Alemg, mas também o público em geral.

A partir da experiência dessas conferências do Núcleo de Programas Especiais - que denominamos Pensando em Minas, um título deliberadamente ambíguo - reunimos o conteúdo das palestras, convidamos novos comentadores para os textos mais polêmicos e editamos uma revista intitulada Cadernos da Escola do Legislativo, hoje com quatro números publicados. Já estiveram aqui, e foram publicados, artigos de Roberto Mangabeira Unger, Alain Badiou, Roberto 
Romano, Jacob Rogozinski, Renato Janine Ribeiro, Paulo Sérgio Pinheiro, Fábio Konder Comparato e Paul Singer, dentre outros.

A Escola do Legislativo sofreu mutações ao longo destes últimos quatro anos. A troca sucessiva de diretores e a obediência cega às "estratégias" definidas e centralizadas pela Diretoria Geral transformaram as prioridades iniciais e modificaram a estrutura acima descrita. Não vale a pena descrever aqui o que ocorreu, as idas e vindas em seus objetivos, nem fazer juízos de valor ou análises detalhadas, mas podemos identificar um novo norte, centrado em um curso de especialização lato sensu sobre o processo legislativo, na área de ensino.

O importante era não perder o fôlego pedagógico inicial.

Paralelamente, nesse período, trabalhamos a educação para a cidadania em outras frentes: pudemos acompanhar a elaboração de um outro vídeo educativo e escrever um texto que servisse ao professor em sala de aula. Fizemos o vídeo Legislativo: Caminhos da democracia, retomando a idéia de buscar ativamente os alunos da rede pública, agora de $1^{\circ}$ e $2^{\circ}$ graus. Trata-se de um vídeo educativo-institucional em que, com linguagem videográfica adequada, recolocamos o assunto Política no cotidiano dos alunos, através de uma analogia simples com uma festa de fim de ano, e ressaltamos a importância da democracia representativa e do federalismo, além de demonstrar de forma clara o papel dos três Poderes, com uma ênfase, claro, sobre o Legislativo. Graças à gentileza do professor Roberto Romano, que leu o texto antes de sua publicação, fizemos vários questionamentos ao professor destinatário, como, por exemplo, o papel das minorias numa democracia e os limites do federalismo no Brasil de hoje. Reproduzimos 1.300 cópias, e até o momento já foram distribuídas, gratuitamente, mil fitas. Ressalte-se que as escolas da rede pública receberam previamente uma correspondência assumindo o compromisso de exibir a fita aos alunos. Outro dado importante era saber que todas as escolas públicas de Minas Gerais já possuíam aparelho de TV e vídeo. Há, sim, uma grande ociosidade desses equipamentos, decorrente muito mais da pouca disponibilidade, no mercado, de fitas de qualidade na área de educação, do que da falta de recursos financeiros para comprá-las.

Não gostaria de utilizar todo o espaço para apenas descrever as várias atividades do Poder Legislativo Estadual, mas algumas delas são importantes no conjunto das atitudes que, de forma direta ou indireta, ampliariam a noção de cidadania em nosso estado. Afinal, não há nada 
mais pedagógico do que a participação efetiva nos processos de decisão.

Pioneiramente, buscou-se a informatização total da Alemg, o que possibilitou um trabalho integrado entre os setores da Casa, e uma agilidade na troca de informações.

Depois definiu-se a criação da Assembléia On-line, interligada a diversas Câmaras Municipais ou entidades de classe, a qual permite ao cidadão comum não só acompanhar toda a tramitação das proposições de lei, como ter acesso ao banco de dados da legislação mineira e do Prodasen (Processamento de Dados do Senado) em Brasília. Hoje já contamos com uma home-page própria no ar (www.almg.gov.br) por meio da qual qualquer internauta pode consultar e fiscalizar o Diário do Legislativo. Ressalte-se a garantia de acesso gratuito a todos os funcionários da Casa.

Depois veio a realização de Seminários Legislativos, que têm como objetivo discutir, com ampla participação da sociedade, temas de interesse público, com a finalidade de colher subsídios para as ações do Legislativo. Importantes por trazerem a uma mesma mesa os principais oponentes com interesses diversos. Ali, apreendem a importância de uma argumentação sustentável e do instrumento político do voto em plenário. Já foram realizados vários encontros, entre os quais destacam-se os que trataram da educação, da questão fundiária, da habitação, das águas, e que se transformaram em algumas leis estaduais, tais como a que dispõe sobre a política estadual de desenvolvimento agrícola e a que dispõe sobre a política estadual de saneamento básico, dentre outras.

A seguir, veio a institucionalização dos Fóruns Técnicos, que se distinguem dos Seminários Legislativos por sua dimensão e pela sistemática de discussão e votação. Têm também o objetivo de colher subsídios para as ações da Assembléia, por meio da ampla participação dos setores interessados, de forma direta, sem a figura do representante em primeiro lugar. Num convênio com a Secretaria do Estado da Cultura, foram convidados a redigir o projeto de lei que dispõe sobre a política cultural do estado de Minas Gerais profissionais das áreas de arqueologia, museologia, biblioteconomia, arquivos, teatro, cinema, vídeo, entre outros. Em reuniões semanais, durante o 20 semestre de 1992, definiram, eles próprios (com auxílio indispensável dos técnicos da consultoria e pesquisa), o texto que deveria entrar em tramitação na Alemg. Os depu- 
tados assumiram o compromisso de aprová-lo, na íntegra. A experiência foi repetida quando da definição da legislação para a inspeção e a fiscalização de produtos de origem animal em nosso estado. Creio que uma análise mais extensa, no futuro, indicar-nos-á que os Fóruns Técnicos puderam e podem ainda contribuir para a superação daquilo que o filósofo francês Alain Badiou chamou de idéia da dupla representação. ${ }^{4}$

Com a realização das Audiências Públicas Regionais pelo interior do estado e a participação dos outros dois Poderes - Executivo e Judiciário - , o modelo das APR estava consolidado. Estas objetivam oferecer ao poder público um conhecimento cada vez mais aprofundado das realidades regionais de Minas, com vistas ao planejamento socioeconômico do estado, estabelecer um canal direto de comunicação entre os municípios e o cidadão e gerar subsídios para a elaboração de leis, principalmente a orçamentária. Entramos neste ano de 1997 em sua terceira versão, e são sempre realizadas no primeiro semestre a cada dois anos, em cidades-pólo das macrorregiões do estado. Além de educar e desmitificar a elaboração do Orçamento Anual, familiarizam o cidadão comum com o jogo parlamentar. Buscou-se, paralelamente, a implantação de um banco de dados sobre organização administrativa, entidades profissionais e de classe, dos municípios mineiros. Mais uma vez, a idéia é tornar a informação disponível a quem dela necessita, além de se permitir uma fiscalização mais rigorosa dos gastos do Executivo.

Aconteceram ainda os Ciclos de Debates. Trata-se de estimular uma discussão sobre os temas mais candentes do momento, com personalidades-chave nesse processo. Revelaram-se extremamente úteis no período previsto para a Revisão Constitucional, por debater os próprios limites daquela revisão.

Por fim, e simultaneamente, aconteciam o Assessoramento à Comissão Interestadual para o Desenvolvimento Sustentável da Bacia do Rio São Francisco e o Parlamento das Águas. Numa decisão inédita, o Legislativo mineiro chamou a si a responsabilidade de definir uma política macroeconômica e de suma responsabilidade no futuro.

Quanto ao setor de publicações, destaca-se ainda a Coleção Passoa-Passo, que já editou e distribuiu mais de 20 mil exemplares do "Processo Legislativo" e do "Participação Política" na Assembléia mineira. Em nome dessa Casa, institucionalmente são editados também a Revista do Legislativo, de divulgação dos principais temas no âmbito deste Poder, e o Boletim Assembléia Informa, com a agenda e a pauta do dia, além de um resu- 
mo dos pronunciamentos dos deputados em Plenário ou nas comissões. Há uma disseminação dessas informações, via fax, para as principais agências de notícias do interior. Completam o quadro a elaboração e a distribuição de um clipping diário - cópias xerográficas de notícias que envolvam a instituição ou os deputados estaduais, na imprensa local e nacional; a transmissão de um programa diário no rádio e na TV, com um resumo de dois minutos dos principais acontecimentos do dia na Alemg. Este é retransmitido nas principais emissoras da capital e do interior de Minas.

Nestes últimos anos enriquecemos nossa disposição pedagógica com o convênio com a Escola de Governo de São Paulo (sob direção do professor Fábio Konder Comparato) e realizamos um curso de formação política, aberto a qualquer interessado. Para prefeitos e vereadores do interior do estado efetivamos o projeto Nova Gestão Pública Regionalizada, no qual detalhamos a organização e as funções do poder público, bem como desnudamos a responsabilidade dos agentes políticos e a racionalidade administrativa.

Junto ao setor universitário, convidamos alunos e professores de Direito Constitucional para a jornada universitária na qual, durante uma manhã, eles acompanham in loco a elaboração das leis, além de explanações e debates com o corpo técnico e parlamentar.

Todos esses recursos pretendem servir de estímulo à participação do cidadão no jogo democrático, ou seja encaminhando à Alemg denúncias de quebra de contratos na lei de defesa do consumidor ou de ilegitimidade ou ilegalidade na utilização de recursos públicos, ou seja, facultando aos eleitores o exercício do direito de apresentar projetos de lei, com iniciativa direta, através de entidades da sociedade civil, direito estabelecido no art. 67 da Constituição Estadual.

\section{0 pretérito do futuro}

Acreditávamos, em 1994, que, se a Escola do Legislativo e a Assembléia Legislativa desejassem, de fato, a participação popular no foro das decisões do Parlamento, não poderia desprezar a eficácia e o alcance da televisão.

Apresentei proposta de uma TV Legislativa na 46 ${ }^{\text {a }}$ Reunião da SBPC, ocorrida em Vitória, no Espírito Santo, no ano de 1994. 
Imaginávamos uma TV montada nos moldes da $B B C$ londrina, embora de dimensões adequadas à nossa realidade: uma parte jornalística, outra pedagógica. Tudo o que ocorresse no espaço físico da Assembléia Legislativa e dissesse respeito à atividade parlamentar seria de responsabilidade da Comunicação Social. O que dissesse respeito à produção de vídeos educativos seria de responsabilidade da Escola do Legislativo, desde que os recursos existissem para ambos e fossem equânimes. As discussões em Plenário ou nas comissões teriam acompanhamento ao vivo, bem como as palestras na Escola do Legislativo, ou mesmo os debates dos Seminários Legislativos.

Em 1994 sabíamos que uma proposta dessas dimensões deveria ser mais bem estudada e analisada por especialistas da área e por todos os setores envolvidos. Foi o que fizemos. Isso, no entanto, não nos impediu de dialogar com membros do staff administrativo que pensavam diferentemente de nós:

"O efeito será o inverso do esperado, pois mostraríamos as deficiências do corpo parlamentar (com as exceções de praxe), afastando ainda mais o eleitor da política parlamentar."

\begin{abstract}
"Não é verdade. A possibilidade inédita de penetrarmos em vários lares, num primeiro momento, certamente dará nova responsabilidade ao deputado no exercício da atividade parlamentar. Depois, a imagem do bom político impregnaria a memória do telespectador, fazendo desse um eleitor em potencial. Por outro lado, os limites e a vaidade pessoal de cada um impedirão que se exponham ao ridículo. A TV servirá, sim, como um panóptico às avessas, onde, ao contrário do sistema proposto por Jeremy Bentham, ${ }^{5}$ o todo vigia a parte, ou seja, boa parcela da população mineira acompanharia de perto seus representantes. Num estado das dimensões de Minas Gerais isso se torna fundamental".
\end{abstract}

"Não haverá ninguém para assistir às reuniões pela telinha, assim como hoje ninguém comparece às galerias (com a exceção de quando seus próprios interesses estão em jogo), ainda que franqueadas ao público." 
"Ninguém comparece às galerias porque não há tempo, nem disposição; e principalmente, porque não se compreende o jogo do processo legislativo, nem os projetos ali apresentados. A TV Assembléia poderia, caso a Escola detenha parte de sua programação, incumbir-se de instruir o telespectador acerca dos mecanismos do processo e esclarecer o que se passa no Plenário ou nas comissões. Por outro lado, por se tratar de uma TV institucional e educativa, não comercial, não teríamos a espada do Ibope sobre nossas cabeças. Nem mesmo os apuros estético e editorial seriam pré-requisitos. Pelo seu ineditismo, cada telespectador seria conquistado na mesma proporção do alcance de sua cidadania."

"Por que investir em despesas tão volumosas quando já temos um programa diário, em praticamente todas as emissoras do estado?"

"A natureza da proposta é outra. Não se trata mais de apenas divulgar os temas e os acontecimentos cotidianos numa linguagem jornalística, e, sim, de revelar todas as dimensões do trabalho parlamentar, em tempo real. E mais: a transmissão ao vivo pode levar a que, no futuro, tenhamos a participação direta do telespectador nas decisões legislativas em pauta. A experiência (com todas as limitações e os maniqueísmos) de envolver a opinião do telespectador em temas candentes já é uma realidade em algumas emissoras comerciais. A democracia, acreditamos, exige criatividade para que possamos desenvolver todas as suas possibilidades e persistência para que as informações públicas e completas alcancem a maior parte da população."

Por uma feliz coincidência, a Lei no 8.977, de 6 de janeiro de 1995, abria a possibilidade para os parlamentos estadual e municipal deterem um canal de TV a cabo das concessionárias locais. E a ALEMG, mais uma vez, não se furtou a ser pioneira nesta área.

Em realidade, de 1994 até hoje, houve transformações completas nas posturas das pessoas envolvidas nesse projeto. A TV Legislativa a cabo, canal 40, tornou-se uma realidade irreversível. Ainda que adstrita aos assinantes e, por enquanto, aos da capital do estado, já colhemos resultados surpreendentes com os telespectadores que zapeam e param nesse canal. 
A programação atual centra-se exclusivamente na área jornalística sem uma definição orçamentária que garanta a participação da Escola do Legislativo no desenvolvimento de projetos de educação para a cidadania. Já elaboramos pré-projetos com pequenas participações, como as Pílulas constitucionais, Memória política de Minas Gerais, Personalidades mineiras, dentre outras, que estão percorrendo os trâmites de convencimento junto ao staff que decide sobre as imbricações políticas de tais programas e sobre o orçamento a ser alocado.

Em realidade, creio que uma proposta dessa natureza só poderá se concretizar se enfrentar os desafios políticos das deficiências da representação, sem receios ou temores de desnudar os três pilares da instituição, a saber: a subserviência do Legislativo Estadual ao Executivo, o clientelismo nas relações entre representante e representado, o corporativismo parlamentar e a impunidade.

Expliquemos melhor, não sem antes dizer que as observações a seguir constituem uma regra, a que não faltam exceções.

\section{A subserviência do Legislativo estadual}

Há, por parte dos deputados, um entendimento precário dos princípios de isonomia e independência entre os Três Poderes, característica substantiva da atuação do Parlamento nas democracias modernas. Antes, buscam um alinhamento automático com o Executivo, como se, de um lado, constituir um bloco de sustentação ao governador fosse tarefa prioritária do Legislativo, e, de outro, participar desse alinhamento revelasse prestígio e força política. Abandonam voluntariamente sua prerrogativa de influir ou exercer um poder de fato, abdicando em favor do outro. O Executivo, por sua vez, ainda define as políticas públicas mais importantes do estado distante do Legislativo, ou, quando muito, ouve as demandas do corpo parlamentar apenas para restabelecer uma prática varejista, na qual o deputado é atendido individualmente, sem caracterizar uma postulação do Poder Legislativo.

O cientista político Fernando Luiz Abrucio, em "Barões da Federação", sua tese de mestrado defendida na USP, demonstra que a facilidade com que o governador de estado consegue passar seus projetos pela Assembléia Legislativa não é prerrogativa dos estados de economia menos desenvolvida. O estado pesquisado em que o Executivo tinha 
maioria mais folgada ( $88,3 \%$ das cadeiras) no Legislativo foi o de Minas Gerais, segunda maior economia do país.

Talvez um pouco de história política de Minas Gerais nos auxilie a entender melhor tal fenômeno.

Um pouco de história

A Assembléia Legislativa Provincial mineira, instituída pelo Ato Adicional de 1834, ganhou existência efetiva no ano seguinte. Período regencial de grandes movimentações políticas, assistia-se então a um conturbado embate nos quadros dirigentes da jovem nação. Inseguros desde a abdicação de Pedro I, os senhores locais buscavam ditar suas precárias normas de convivência, atentos ao que ocorria em outras províncias, no Império do Brasil. E as notícias de fora não eram nada tranqüilizadoras. Ao contrário, as várias revoltas e rebeliões que eclodiam por todo o território nacional tornavam insones e desnorteados os novos condutores da política que por isso mesmo se apegavam ferreamente à ordem constituída. Como registro desse apego, podemos ler nos Anais da Assembléia Provincial, às vésperas do Golpe da Maioridade, uma representação de vários parlamentares à Assembléia Geral, no Rio de Janeiro, para que essa percebesse "a urgente necessidade de se decidir quanto antes a interpretação do Ato Adicional", pois "(...) as facções e partidos armados, rebelando-se contra as instituições, surgem aqui e ali, como um pernicioso contágio, que vai lavrando de umas para outras Províncias". ${ }^{6}$

À época, as Assembléias Legislativas desfrutavam de um poder legislativo absolutamente amplo, que abrangia desde a divisão civil, judiciária e eclesiástica da Província, passando pela definição de impostos provinciais e municipais, até a criação e a nomeação de empregos. Nunca, em toda a história do Parlamento estadual, gozou o Legislativo de tanto poder. No entanto, pairavam ainda muitas dúvidas quanto aos limites de atuação dos presidentes de província e mesmo da Assembléia Geral. Tanto poder de nada servia se os ecos da desordem de outras províncias continuassem impedindo o bom sono da elite dirigente. Aos conservadores, que retomavam as rédeas da política nacional, cumpria instituir um governo forte, centralizado na Corte, que definisse regras claras e comuns a todas as instâncias de poder e em todo o território nacional. Estava aprovada a Lei de Interpretação do Ato Adicional, de 1840, 
que retirou várias prerrogativas das Câmaras regionais. Com o beneplácito da maioria dos representantes dos proprietários - votantes majoritários naquele regime censitário - a Assembléia Provincial permutou a amputação de sua esfera legislativa pela manutenção segura e efetiva de seus monopólios (terra e escravos), cuidadosamente herdados desde a Colônia. A direção conservadora, ao colocar em xeque a política liberal (responsabilizada indiretamente pela desordem), demarcava as novas bases para a atuação dos representantes. A troca fora proposta, realizada e aceita, quase sem oposição. A exceção dos primeiros momentos ficou por conta do jovem Teófilo Ottoni e do padre José Marinho na revolta de 1842. A derrota de Santa Luzia, no entanto, marcaria para sempre as diferenças sutis entre os saquaremas (conservadores) e luzias (liberais), impingindo a esses a pecha de derrotados.

Este gesto fundante, de abdicação de uma função política em troca de uma segurança patrimonial, é a característica histórica marcante deste Poder, que reencontraremos em outros tempos, inclusive no atual.

A partir do Golpe Militar de 1964, e com os conseqüentes Atos Institucionais decretados, o Poder Legislativo estadual vive uma situação anômala, mas que marcará profundamente seu comportamento a posteriori: ao contrário do ocorrido na ditadura estado-novista, a Casa Parlamentar permaneceria aberta, sendo-Ihe retiradas, no entanto, todas as prerrogativas que pudessem entrar em choque com os interesses do Estado ou que afrontassem a Lei de Segurança Nacional.

A Assembléia Legislativa de Minas Gerais, como as demais do país, deixaria de exercer suas prerrogativas para apenas legitimar o Estado de exceção que vigorava. Deputados identificados como oposição ao novo regime tiveram cassados seus mandatos por seus próprios pares. Com o funcionamento esvaziado do Legislativo - restrito ao fornecimento de declarações de utilidade pública, à denominação de escolas, hospitais e pontes, e a uma infinidade de requerimentos inúteis - assistimos assim, nesse período, a uma transferência de poder, pelo suporte institucional-democrático, aos governos militares. Aos que não aceitassem participar desse jogo de aparências, restaria o ostracismo político ou a clandestinidade partidária, o que aumentou em muito as chances eleitorais de quem usufruía do jogo. A censura à imprensa e a impossibilidade de fiscalização administrativa foram campo fértil para a corrupção e o nepotismo, porta aberta do Estado, sem o critério meritório do concurso público. Criou-se uma estrutura pesada, de funcionários ineficientes, para um trabalho vazio. 
Três conseqüências desse tempo: o vácuo de novas lideranças políticas (devido à repressão da época), a prática do ingresso na administração sem concurso público (vários servidores de recrutamento amplo, de cargos de confiança dos deputados, foram sendo lentamente incorporados à estrutura da Alemg, com o beneplácito do staff administrativo da época, que também aproveitava a porta arrombada e colocava seus familiares) e a subserviência ao Executivo. Se é fato que estamos caminhando para superar as duas primeiras, o mesmo ainda não podemos dizer da terceira.

\section{0 clientelismo}

Assim, não há por que desconhecer que se, de um lado, o relacionamento entre alguns deputados e os governantes permanece pautado por uma permuta que hoje lhe é extemporânea, de outro, não há muita novidade no relacionamento - instituído também no passado - entre os parlamentares e os eleitores.

As chamadas bases eleitorais parecem exigir que o comportamento político do representante seja perene na forma conhecida, isto é, que permaneçam em vigor, mesmo na democracia representativa plena, as moedas de troca entre o eleitor e o eleito.

E, aqui, os nós górdios do emperramento democrático se complicam. A maioria dos eleitos aprendeu a participar do jogo parlamentar nas Câmaras Municipais, o que Ihes estimulou a perenizar suas atitudes quando no exercício do mandato estadual. Exercem esse jogo com compreensão da política local, miúda, de atendimento a pequenas demandas, obstando um entendimento macroestrutural, o que é grave num estado das dimensões de um país como a França. O foco e a energia do esforço parlamentar, que deveriam contemplar políticas públicas estruturais, estacionam em pequenos problemas regionalizados. Os eleitores, por sua vez, menos ainda acostumados às novas regras que uma democracia representativa institui, reafirmam sua disposição de só eleger os que olham sua região. As deficiências de nosso federalismo e a excessiva centralização dos recursos em mãos da União ou dos estados transformam o deputado num autêntico despachante de luxo. Aqui, mais uma vez, o Executivo - poder que de fato deve cuidar da execução de obras e gerenciá-las - encontra terreno fértil para alargar seu cacife, na hora 
da troca de apoios. O terror que assola todo político de não se reeleger - o lado escuro do ostracismo - cria um círculo vicioso em que a regra da vitória eleitoral já foi dada pela história pregressa. Acrescente-se ao quadro os esforços familiares para preservar seus monopólios eleitorais, ancorados em tradições de nome, os quais, mesmo em fins do século XX, ainda podem dar resultados.

\section{Corporativismo parlamentar interno}

Como as últimas eleições parlamentares de 1994 demonstraram, é de supor que ocorrerá novamente uma grande renovação de nomes no corpo parlamentar, sem, no entanto, uma mudança qualitativa de comportamento dos novos eleitos.

Os que saíram, ou não teriam correspondido às expectativas dos que os elegeram, ou seriam vítimas da indignação do eleitor com os abusos que a imprensa não cansou de imputar aos parlamentares. Ou, enfim, não seria nada disso, apenas a desmemória geral da população em relação a seus representantes. Um consenso no conjunto das hipóteses, entretanto, se apresenta: há uma erva daninha no Parlamento chamada corporativismo.

Se cada vez mais a sociedade civil vem percebendo os emperramentos que o corporativismo traz aos vários setores do Estado ou da iniciativa privada (vide universidades, secretarias, órgãos de economia mista etc.), não seria diferente com relação aos eleitos.

O corporativismo parlamentar tem faces diversas. Em primeiro lugar, a segurança financeira. Todos passam, automaticamente, a fazer parte de um grupo seleto, no qual subsídios confortáveis no presente e aposentadorias generosas no futuro os igualam a uma casta privilegiada, distante de uma sociedade cada vez mais empobrecida. Reforçam a distância, cada vez maior no Brasil, entre os que possuem capital e os despossuídos.

Os novos eleitos, tendo como experiência parlamentar apenas sua passagem pelas Câmaras Municipais, recebem dos veteranos parte do aprendizado. E por mais que haja diferenças políticas substantivas, é de se esperar uma cordialidade interpares, o que, no fundo, possibilita o funcionamento da máquina legislativa. Lentamente, no entanto, forma-se um 
sprit de corps, que os iguala em comportamento e responsabilidade. Aquelas atitudes do clientelismo e do paternalismo, já descritas anteriormente, contaminam de forma avassaladora os novos parlamentares, que, mais uma vez, vêem na reeleição do colega um receituário de como retornar à Casa Legislativa. A responsabilidade de permanecer no mandato deixa de ser uma responsabilidade entre eleitor-eleito, representado-representante, para sê-la entre eleito-eleito. Cria-se, então, o fenômeno do corpo parlamentar, fechado, onde qualquer ameaça externa a um parlamentar repercute como uma ameaça a todos. Ainda podemos assistir nos dias de hoje à tentativa da Justiça Eleitoral de processar políticos acusados de irregularidade em sua vida pública ou mesmo de crimes comuns encontrar obstáculos rigidamente colocados na Comissão de Constituição e Justiça das Casas Legislativas. Aqui, mais uma vez, temos de abrir espaço para as exceções de praxe.

Tal transferência de responsabilidade mostra-se de forma ainda mais crua na troca constante de siglas partidárias, prática comum entre parlamentares. Seus compromissos e fidelidades aos partidos políticos esvaem-se no primeiro aborrecimento da disciplina ou na contribuição financeira compulsória. Influencia ainda a mudança de partido a perspectiva de um guarda-chuva sólido - geralmente atrelado ao Executivo. Trata-se de um quadro político ruim para a consolidação da democracia representativa. Nele, os partidos deixam de se instrumentalizar como componentes indispensáveis da educação política para se transformarem em meras siglas, sem significado aparente para o eleitor. Reforçam-se, assim, a convicção e o senso comum de que o partido político nada vale, e de que só o indivíduo - o nome, a família pesa no jogo eleitoral.

Notas

1. As conferências dos professores Raymundo Faoro e Francisco Iglésias foram publicadas pela Assembléia Legislativa de Minas Gerais, ainda no ano de 1986. Nos anais do referido simpósio.

2. Trata-se, aqui, do título de um artigo do professor Roberto Roamo (Unicamp), publicado na Folha de S. Paulo.

3. Ver Cadernos da Escola do Legislativo, vol. 1, jan.-jun./1994, pp. 3-7.

4. Ver Cadernos da Escola do Legislativo, vol. 1, jan.-jun./1994, pp. 59-81. 
5. Ver Revista Brasileira de História, n 14, vol. 7, mar./ago. 1987, pp. 199-229.

6. Ver Cadernos da Escola do Legislativo, vol. 1, jan.-jun./1994, p. 157.

\section{Education for citizenship: Experiences of the Legislative' School}

ABSTRACT: This report presents the Legislative' School, a pioneer idea from the Minas Gerais State Legislative Assembly - an institution that provides knowledge and stimulates thought in the area of learning, research and university extension. The report gives a brief history of its establishment and then talks about the advances of the school towards editorial and educational practices in citizen education the challenges of using apropriated technological tools: T.V. and Internet are also discussed. The report did not neglect to reveal the institutional and historical limitations for a truly democratic and citizen participation: subservience of the Legislative to the Executive branch, the patronage in the relationship between the representative and the constituent, the parliamentary corporation and impunity. 